\title{
ZINC UPTAKE AND DISTRIBUTION IN IVY (Hedera helix L.) LEAVES
}

\author{
JANA MAREŠOVÁ ${ }^{1}$, MIROSLAV HORNÍK $^{1,2}$, MARTIN PIPÍŠKA $^{1,2}$, \\ JOZEF AUGUSTÍN ${ }^{1,2}$ \\ ${ }^{I}$ Department of Biotechnology, University of SS. Cyril and Methodius, Nám. \\ J. Herdu 2, Trnava, SK-917 01, Slovak Republic (hornikm@ucm.sk) \\ ${ }^{2}$ Consortium for Environmental Biotechnology and Environmental Chemistry, \\ Hlavná 418, Špačince, SK-919 51, Slovak Republic
}

\begin{abstract}
Detached leaves of ivy (Hedera helix L.) were used as a model for the study of zinc uptake and transport in vascular plants. By the uptake via the surface of fully immersed leaves in $25 \%$ Hoagland nutrient media (HM) spiked with ${ }^{65} \mathrm{ZnCl}_{2}\left(50 \mu \mathrm{mol} / \mathrm{dm}^{3} \mathrm{ZnCl}_{2}\right)$, concentration in leaves $4.98 \mu \mathrm{g} \mathrm{Zn} / \mathrm{g}$ (dry wt.), i. e. $2.6 \mu \mathrm{g} \mathrm{Zn} / \mathrm{dm}^{2}$ leaf area after $7 \mathrm{~d}$ exposition were obtained. By the uptake via immersed stalks of not immersed (transpiring) leaves concentrations up to $370 \mu \mathrm{g} \mathrm{Zn/g} \mathrm{(dry} \mathrm{wt.)} \mathrm{were} \mathrm{obtained.} \mathrm{When} \mathrm{Zn} \mathrm{enters}$ into detached leaves via the surface of immersed leaf blades, zinc is uniformly distributed in leaf blades and leaf stalks. When zinc enters detached leaves via immersed stalks of non-immersed transpiring leaves, only small part of zinc is transported to leaf blades and the prevailing part remains in leaf stalks. Stalks act as a trap, able to prevent other leaf tissues against inhibitory effects of high $\mathrm{Zn}$ concentrations. Mineral nutrient salts in solutions mobilize $\mathrm{Zn}$ trapped in leaf stalks and facilitate $\mathrm{Zn}$ transport by transpiration stream to leaf blades, what means that $\mathrm{Zn}$ in stalks is bound in ion-exchageable forms.
\end{abstract}

Keywords: zinc, ${ }^{65} \mathrm{Zn}$, foliar uptake, distribution, Hedera helix.

\section{Introduction}

Foliar uptake of mineral nutrients is of practical importance in agriculture and the problem was well described in numerous patents, periodicals and reviews (MARSCHNER, 1995). Zinc is an essential nutrient as a trace element for animals, plants, and microorganisms. Studies with wheat showed good transport of $\mathrm{Zn}$ from stalks and leaves to developing grain (PEARSON et al., 1995; 1996), as well as from one root to another (PEARSON and RENGEL, 1995), indicating involvement of phloem transport. The movement of foliar - applied $\mathrm{Zn}$ to plant roots was demonstrated in small number of studies (HASLETT et al., 2001).

Radiotoxic ${ }^{65} \mathrm{Zn}$ is produced, sometimes in copious quantities, by neutron activation of stable $\mathrm{Zn}$ in nuclear reactors. Due to its half-life $(\tau=244 \mathrm{~d})$ and biological mobility, ${ }^{65} \mathrm{Zn}$ can be transported through food chains to man. ${ }^{65} \mathrm{Zn}$ may be taken up through leaves and roots by plants and its uptake is strongly influenced by nuclide form and soil properties (BRAMBILLA et al., 2002).

English ivy (Hedera helix L.) is a common, easily available plant species, possesing a number of advatages and its leaf ultrastructure is well described (CANET et al., 1996; GILLY et al., 1997). Ivy leaf cuticle was used as a suitable model to investigate cuticular permeability. CHAMEL (1986) described the fine structure and permeability of ivy leaf cuticles in relation to foliar development and after selective chemical treatments and determined the relationship between structure and permeability. 
Our previous papers were oriented on the bioaccumulation of ${ }^{137} \mathrm{Cs},{ }^{60} \mathrm{Co}$ and ${ }^{65} \mathrm{Zn}$ from nutrient solutions and translocation in vascular plants (HORNÍK et al., 2007; BARÁTOVÁ et al., 2006). The objective of this study was to quantify the uptake of zinc by detached leaves of ivy (H. helix L.) submerged in solutions spiked with ${ }^{65} \mathrm{ZnCl}_{2}$ in short-time laboratory experiments. Two pathways of $\mathrm{Zn}$ uptake and translocation, i.e. from stalks to leaf blades and from leaf blades to stalks were compared under the same experimental conditions. We used detached ivy leaves fully immersed in $\mathrm{ZnCl}_{2}$ solutions, instead of spraying, in order to eliminate differences in uptake values caused by different droplet volumes and contact surface areas, described by MERCER (2007) and by other researchers.

\section{Materials and methods}

\subsection{Plant material}

Ivy branches (H. helix L.) were collected during spring months from freely grown garden vegetation. The upper part of branches were cut from a wild ivy plant, washed repeatedly in deionized water and used for experiments. Leaves of about $0.2-0.3 \mathrm{~g}$ fresh weight and of leaf area $11.5-12.5 \mathrm{~cm}^{2}$ were used in experiments.
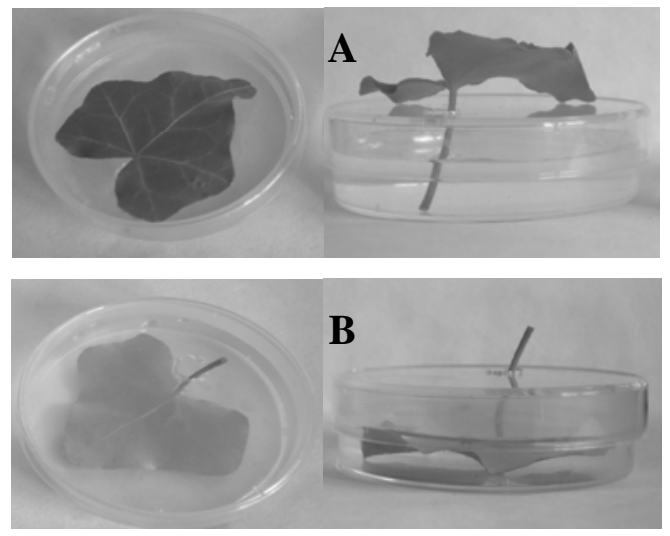

Fig. 1. Photo of ivy leaves in experiments. Characteristic signs: short stalks; shallow sinus; well developed veins; terminal, lateral and basal lobes. A. leaf stalks immersed in nutrient media in Petri dishes; B. Only leaf blades immersed in nutrient media in Petri dishes.

\subsection{Bioaccumulation experiments}

\subsubsection{Uptake via stalks of detached transpiring leaves}

Leaf stalks $(1.5 \mathrm{~cm})$ were immersed in $10 \mathrm{ml} \mathrm{25 \%}$ Hoagland medium (HM, HOAGLAND, 1920) supplemented with $5 \mu \mathrm{mol} / \mathrm{dm}^{3} \mathrm{ZnCl}_{2}$ spiked with ${ }^{65} \mathrm{ZnCl}_{2}$ and incubated in a cultivation room, at $22 \pm 2^{\circ} \mathrm{C}$ under illumination with artificial light (2 $000 \mathrm{~lx})$ in $12 \mathrm{~h} / 12 \mathrm{~h}$ light/dark period (Fig. 1A). The full-strength HM medium 
consisted of following molar concentrations of salts (in $\mathrm{mM}$ ): $\mathrm{MgSO}_{4} \cdot 7 \mathrm{H}_{2} \mathrm{O}-1.5$; $\mathrm{KNO}_{3}-4.0 ; \mathrm{CaCl}_{2}-4.0 ; \mathrm{NaH}_{2} \mathrm{PO}_{4} .2 \mathrm{H}_{2} \mathrm{O}-1.87 ; \mathrm{Na}_{2} \mathrm{HPO}_{4} .12 \mathrm{H}_{2} \mathrm{O}-0.13$; $\mathrm{FeSO}_{4} .7 \mathrm{H}_{2} \mathrm{O}-0.06 ; \mathrm{NaNO}_{3}-4.0 ; \mathrm{NH}_{4} \mathrm{Cl}-3.17 ; \mathrm{NH}_{4} \mathrm{NO}_{3}-2.0 ; \mathrm{H}_{3} \mathrm{BO}_{3}-0.14$; $\mathrm{Na}_{2} \mathrm{MoO}_{4} .2 \mathrm{H}_{2} \mathrm{O}-0.0025 ; \mathrm{MnSO}_{4} .5 \mathrm{H}_{2} \mathrm{O}-0.21 ; \mathrm{ZnSO}_{4} .7 \mathrm{H}_{2} \mathrm{O}-0.023 ; \mathrm{CuSO}_{4} .5 \mathrm{H}_{2} \mathrm{O}-$ 0.033 .

\subsubsection{Uptake via surface area of immersed detached leaves}

Leaf blades of detached leaves were fully immersed in $10 \mathrm{ml}$ of $25 \% \mathrm{HM}$ supplemented with $5 \mu \mathrm{mol} / \mathrm{dm}^{3} \mathrm{ZnCl}_{2}$ spiked with ${ }^{65} \mathrm{ZnCl}_{2}$ in plastic Petri dishes covered with lids (Fig. 1B), under the conditions described in the previous paragraph. Non-immersed leaf surfaces provided transpiration and respiration. At the end of experiments, leaves were carefully rinsed in deionized water and dried at $60^{\circ} \mathrm{C}$ to a constant weight and the incorporated radioactivity was measured by gammaspectrometry. Bioaccumulation experiments were carried out in duplicate series.

\subsection{Radiometric analysis}

A gamma spectrometric assembly using the well type scintillation detector 54BP54/2-X, NaI(Tl) (Scionix, the Netherlands) and data processing software Scintivision 32 (ORTEC, USA) were used for ${ }^{65} \mathrm{Zn}$ determination in plants and solutions. Counting time of $600 \mathrm{~s}$ allowed to obtain data with measurement errors $<2 \%$, that do not reflect other sources of errors. A standardized solution of ${ }^{65} \mathrm{ZnCl}_{2}$ $\left(50 \mathrm{mg} / \mathrm{dm}^{3}{ }^{65} \mathrm{ZnCl}_{2}\right.$ in $\left.3 \mathrm{~g} / \mathrm{dm}^{3} \mathrm{HCl}\right)$ with specific radioactivity $4,901 \mathrm{MBq} / \mathrm{cm}^{3}$ was obtained from The Czech Institute of Metrology (Prague, Czech Republic).

\subsection{Speciation modeling}

The prediction of $\mathrm{Zn}$ speciation in the aqueous systems was performed using the Visual MINTEQ (version 2.53) program. This speciation model allows the calculation of the composition of solutions for specified conditions ( $\mathrm{pH}$, ionic strength, concentration, temperature).

\section{Results and discussion}

Leaf water repellency of adaxial or abaxial surfaces is a main limiting factor in spray application processes (WATANABE and YAMAGUCHI, 1991; HOLDER, 2007). The permeability of the cuticle to water and to lipophilic organic molecules increases with mobility (diffusion coefficients) and solubility (partition coefficients) of these compounds within the transport-limiting barrier of the cuticles and this process is well described. Significantly less is known about the permeability of the cuticle to ionic compounds. However, this is also of major significance in agriculture since, in foliar nutrition, elements such as zinc and copper can be sprayed as foliar fertilizers on leaf surfaces. In order to be effective, these ions have to penetrate the lipophilic cuticle. Recently, significant progress has been achieved in measuring cuticular penetration (LIN et al., 2007; SCHLEGEL et al., 2005; FRANKE et al., 2005). 
The aerial surfaces of higher plants are covered with a cuticle, with the exception of stomata openings. The cuticle is an extracellular, lipidic covering layer, forming the interface between the plant and environment. The cuticle represents the main barrier to the penetration of foliar-applied water soluble compounds such as mineral foliar fertilizers. The waxy leaf surface is hydrophobic and therefore surfactants are a common component of foliar formulations used for increasing the leaf wettability and to prolong the contact time of spray solutions with leaf surfaces. Since charged molecules carry hydration shells (STEIN, 1967), they are not soluble in the lipophilic cutin and wax domains of the cuticles.

According to VIOUGEAS et al. (1995) the cuticle mass of ivy leaves increases with increasing age from 234 to $539 \mu \mathrm{g} / \mathrm{cm}^{2}$. Waxes increases from 12.3 to $18.6 \%$ of cuticle mass from young to old leaves. Percentages of cutin and non-lipid constituents do not vary significantly with leaf age. They represent approximately 58 and $26 \%$ of the cuticle mass, respectively. Cuticle thickness increases 12-fold during leaf growth to reach $4.25 \mu \mathrm{m}$ for mature leaves. An outer lamellate zone gradually merging from an inner reticulate zone the thickness of which increases with leaf growth is characterized by a constant thickness of $0.2 \mu \mathrm{m}$. Intracuticular wax is localized in lamellae. Electron-dense fibrillae observed in the reticulate zone are made of non-lipid components (VIOUGEAS et al., 1995).

We can suppose, that $\mathrm{Zn}$ uptake data via leaf surface will be strongly dependent on the age of leaves used in experiments, due to the fact, that cuticle is the major barrier for nutrient leaf uptake.

\subsection{Zn uptake via stalks}

Detached leaves are frequently used for studies of long distance transport in vascular systems of higher plants. The main advantage of such studies is in the elimination of selective effect of root system on different compounds, which takes place in transport studies via root systems of hydroponically grown plants. In our study, stalks of detached leaves of ivy (H. helix) were immersed in $\mathrm{ZnCl}_{2}$ solutions and both, the adaxial and abaxial leaf surfaces were in contact with atmosphere. In this case the only driving force of $\mathrm{Zn}$ uptake was water transport driven by transpiration. We found that under given conditions, the uptake of $\mathrm{Zn}$ was proportional to the initial $\mathrm{Zn}^{2+}$ concentration $\mathrm{C}_{0}$ within the range $\leq 50 \mu \mathrm{mol} / \mathrm{dm}^{3}$. At $\mathrm{C}_{0}=50 \mu \mathrm{mol} / \mathrm{dm}^{3} \mathrm{ZnCl}_{2}$, concentrations of $\mathrm{Zn}^{2+} 370 \mu \mathrm{g} / \mathrm{g}$ and $3.1 \mu \mathrm{g} / \mathrm{g}$ of dry weight of leaf stalks and leaf blades, respectively, were obtained. It means that zinc entering the plant tissues via stalks is distributed by vascular system into leaf blades only in limited extent, reaching a specific concentration ratio of $[\mathrm{Zn}]_{\text {stalks }} /[\mathrm{Zn}]_{\text {blades }}=120: 1$ (Fig. 2A). Which chemical components of stalk tissues are responsible for immobilization of $\mathrm{Zn}^{2+}$ ions via xylem vessels will require more detailed study.

\subsection{Zn uptake via leaf surfaces}

For the $\mathrm{Zn}$ foliar uptake study in our experiments we used detached ivy leaves, fully immersed in $\mathrm{ZnCl}_{2}$ solutions. This approach eliminates the differences in foliar 
uptake from sprayed solutions caused by different droplet volumes and contact surface areas of sprayed solutions, described by MERCER (2007). Under experimental conditions both adaxial and abaxial leaf surfaces were in contact with $\mathrm{ZnCl}_{2}$ solution and transpiration as the main driving force does not participate on $\mathrm{Zn}$ influx into leaf tissues. Influx of nutrients via leaf surfaces is a characteristic route for nutrient uptake by plants without efficient root systems, such as mosses and submerged aquatic plants. Under such conditions the amount of zinc taken up by ivy leaves increased with increasing $\mathrm{Zn}$ concentration in solutions, however the amount of zinc in leaf tissues represented only $33.7 \%$ of that accumulated via leaf stalks.

Data in Fig. 2B demonstrate, that zinc entering plant tissues via leaf surfaces is distributed by vascular system into stalks, reaching the concentration ratios of $[\mathrm{Zn}]_{\text {stalks }}$ $/[\mathrm{Zn}]_{\text {blades }}$ from approximately $1: 1$ to $2: 1$. However this ratio will depend on the zinc concentration in solution. According to KRAMER and KOZLOWSKI (1979) and LIN et al. (1995) the mobility of absorbed elements depends on their concentration in plants.
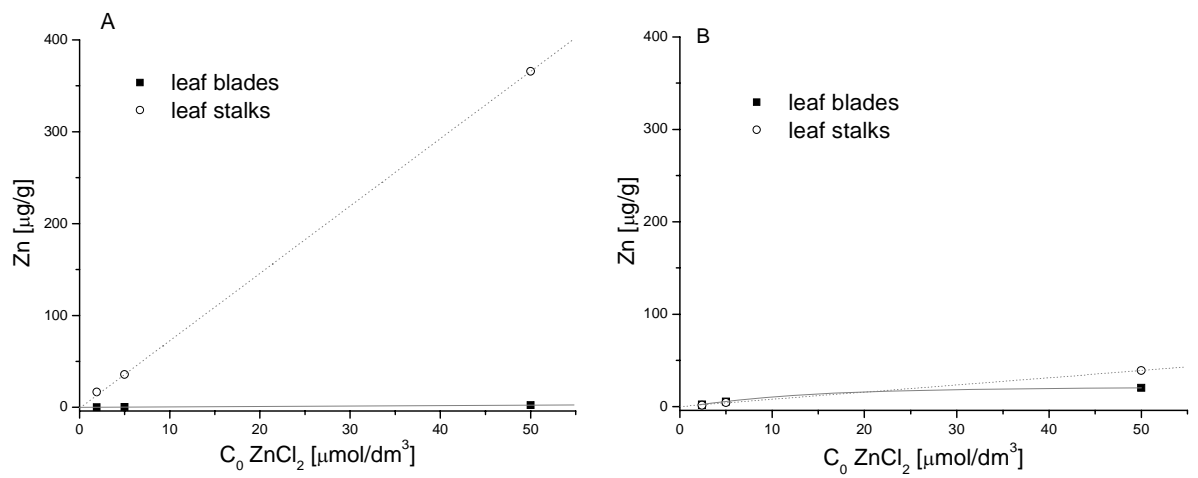

Fig. 2. Zn concentration ( $\mu \mathrm{g} / \mathrm{g}$, dry wt.) in leaf stalks (-‥) and leaf blades (-) of ivy leaves (H. helix L.) after $5 \mathrm{~d}$ exposition in 2.4; 5.0 and $50 \mu \mathrm{mol} / \mathrm{dm}^{3} \mathrm{ZnCl}_{2}$ in $25 \% \mathrm{HM}$ spiked with ${ }^{65} \mathrm{ZnCl}_{2}\left(310 \mathrm{kBq} / \mathrm{dm}^{3}\right)$. A. Uptake via immersed stalks of transpiring leaves. B. Uptake via surface of fully immersed leaves. Cultivation at $12 \mathrm{~h} / 12 \mathrm{~h}$ light/dark period $(2000 \mathrm{~lx}), \mathrm{pH} 6.0$ and $22 \pm 2^{\circ} \mathrm{C}$. Wet weight of leaves $[\mathrm{g} / 10 \mathrm{ml}]$ : A. $0.29 \pm 0.01( \pm \mathrm{SD})$; B. $0.27 \pm 0.01( \pm \mathrm{SD})$. Leaf area $\left[\mathrm{cm}^{2}\right]$ : A. $14.6 \pm 0.75( \pm \mathrm{SD})$; B. $13.7 \pm 0.99( \pm \mathrm{SD})$. B. Transpiration $3.32 \pm 0.74 \mathrm{~cm}^{3} \cdot \mathrm{dm}^{-2} \cdot \mathrm{d}^{-1}( \pm \mathrm{SD})$.

Total $\mathrm{Zn}$ uptake via leaf surfaces was by one order lower comparing with $\mathrm{Zn}$ uptake via xylem path of stalks of detached leaves. This is a consequence of the existence of diffusion barriers on the leaf surfaces, mainly cuticular membrane and waxes and due to the absence of transpiration stream. The driving force for $\mathrm{Zn}$ uptake across the leaf surface is a concentration gradient on the water/leaf interface. Similarly as in the case of $\mathrm{Zn}$ uptake via leaf stalks (Fig. 2A), also in the case of $\mathrm{Zn}$ uptake via leaf blade surfaces of fully immersed leaves (Fig. 2B), Zn uptake increased with increasing initial $\mathrm{Zn}$ concentration $\mathrm{C}_{0}$. However total $\mathrm{Zn}$ uptake expressed as specific concentration in $\mu \mathrm{mol} / \mathrm{g}$ was 9.4 times lower in stalks and 2.8 times higher in leaf blades. 


\subsection{Effect of nutrient salts}

Distribution of zinc entering the leaves of ivy via vascular system of stalk of detached leaves immersed in nutrient medium spiked with ${ }^{65} \mathrm{ZnCl}_{2}$ was dependent on inorganic nutrient concentration (Fig. 3). When $\mathrm{Zn}$ is taken up from low nutrient salt media, i.e. $<50 \% \mathrm{HM}$, substantial part of zinc remains immobilized in stalks.
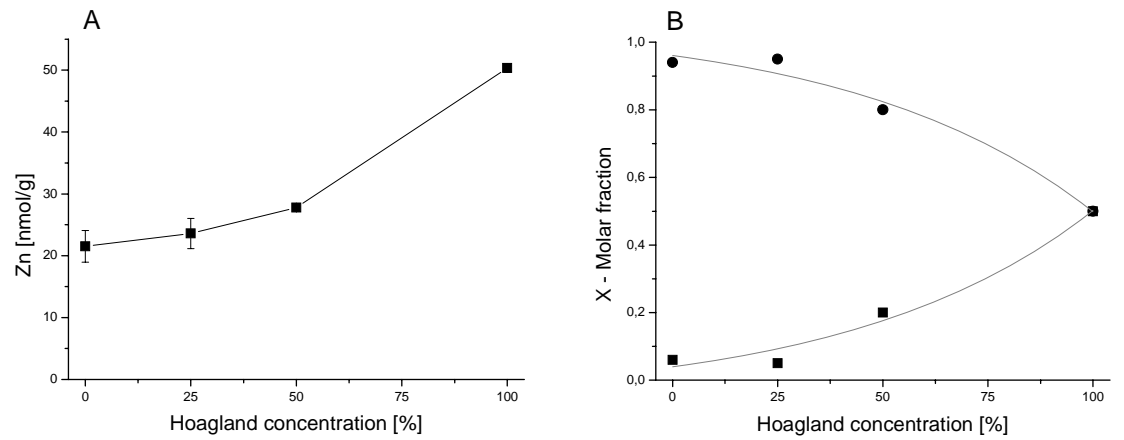

Fig. 3. Influence of nutrient salt concentration on $\mathrm{Zn}$ uptake and distribution in leaf stalks and leaf blades of ivy (H. helix L.). Uptake via immersed stalks of transpiring leaves. Data after $6 \mathrm{~d}$ exposition in diluted HM spiked with ${ }^{65} \mathrm{ZnCl}_{2}\left(310 \mathrm{kBq} / \mathrm{dm}^{3}\right)$ at initial $\mathrm{Zn}$ concentration $\mathrm{C}_{0}: 1.1 ; 1.7 ; 2.3$ and $3.4 \mu \mathrm{mol} / \mathrm{dm}^{3}$. Cultivation at $12 \mathrm{~h} / 12 \mathrm{~h}$ light/dark period $(2000 \mathrm{~lx}), \mathrm{pH} 5.5$ and $22 \pm 2^{\circ} \mathrm{C}$. Data expressed as A: $\mathrm{Zn}$ concentration in ivy leaves $\left[\mathrm{nmol} / \mathrm{g}\right.$, dry wt.]; B: $\mathrm{Zn}$ molar fraction in leaf blades $\left(\mathrm{X}=[\mathrm{Zn}]_{\text {blades }} /[\mathrm{Zn}]_{\text {total }}\right.$; -m-m-n-) and leaf stalks $\left(\mathrm{X}=[\mathrm{Zn}]_{\text {stalk }} /[\mathrm{Zn}]_{\text {total }} ;-\bullet \bullet-\bullet-\bullet-\right)$. Biomass of the whole ivy leaves (stalks + blades) in experiments $\left(\mathrm{g} / 10 \mathrm{ml}\right.$, wet wt.): $0.64 \pm 0.06 \mathrm{~g}( \pm \mathrm{SD})$. Leaf blade area of transpiring leaves: $20.03 \pm 1.26 \mathrm{~cm}^{2}$ $( \pm \mathrm{SD})$. Transpiration rate: $3.33 \pm 0.74 \mathrm{~cm}^{3} \cdot \mathrm{dm}^{-2} \cdot \mathrm{d}^{-1}( \pm \mathrm{SD})$.

When $\mathrm{Zn}$ is taken up from solutions of high nutrient concentrations ( $>50 \% \mathrm{HM})$, zinc is nearly completely transported from stalks to the leaf blades (Fig. 4). We can conclude that zinc entering the leaves via stalk xylem is bound on components of xylem vascular system by reversible ionic bond. Zinc can be replaced from binding sites by ions showing higher activity for binding sites, present in the vascular system. To answer the question which binding sites in xylem vessels play a decisive role in $\mathrm{Zn}$ binding in xylem of individual plant species will require more detailed study.

Our hypothesis is supported by published data describing zinc interaction in other plant tissues. STRACZEK et al. (2008) used chemical extractions and EXAFS spectroscopy for the study of $\mathrm{Zn}$ distribution in whole roots and isolated root cell walls of tobacco plants. Their results showed that the cell walls of roots exhibited a distribution of $\mathrm{Zn}$ from water soluble to non-exchangeable $\mathrm{Zn}$ form. In whole roots, $\mathrm{Zn}$ was bound with oxalate and other $\mathrm{COOH} / \mathrm{OH}$ groups: the first species was probably intracellular while the second was attributed to $\mathrm{Zn}$ bound to the cell walls and, to a lesser extent, to intracellular organic acids. Zn-phosphate was also identified, and this species was $\mathrm{CuSO}_{4}$ - extractable. It probably resulted from chemical precipitation in the apoplast, and explained the steady increase in exchangeable root $\mathrm{Zn}$ observed in tobacco roots during the culture. 


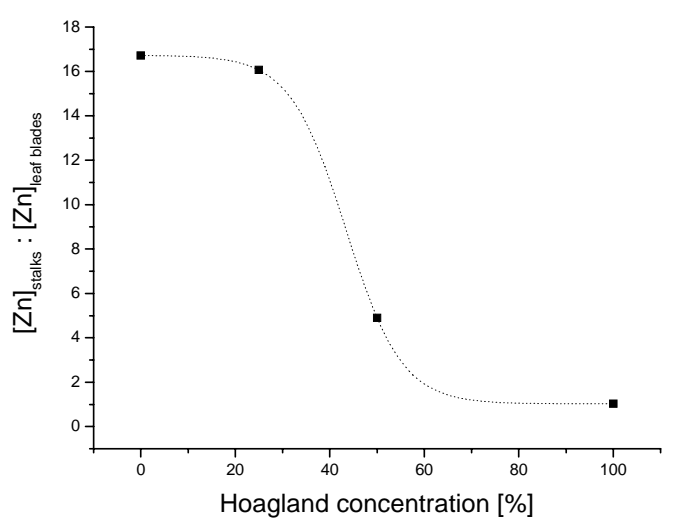

Fig.4. Distribution of $\mathrm{Zn}$ in stalks and blades of ivy leaves after $6 \mathrm{~d}$ uptake via immersed stalks of transpiring leaves, expressed as the $[\mathrm{Zn}]_{\text {stalks }}:[\mathrm{Zn}]_{\text {blades }}$ ratio. Calculated from data in Fig. 2.

Zinc, in optimal concentration, is a typical micronutrient which is necessary for normal metabolism of all plant cells. On the other side, in supra-optimal concentrations, zinc can cause serious damages in metabolically active cells, mainly in leaves. Our data support the idea, that leaf stalk can act as a barrier able to retard transport of $\mathrm{Zn}$ ions entering the leaf via xylem path. This barrier may be less efficient in the presence of higher salt concentrations moving in the root to shoot direction.

\subsection{The effect of $\mathrm{pH}$}

The membrane permeability can be affected by solution $\mathrm{pH}$, mainly by influencing the driving forces via electrical potential and by change of the properties of the solutes by dissociation. The cuticles are polyelectrolytes and their isoelectric point is around pH 3 (SCHÖNHERR and HUBER, 1977). Above this point, when pH increases, the cuticles carry fixed negative charges. These charges are also an important characteristic affecting the water content of the polymer matrix via swelling.

The $\mathrm{pH}$ dependence of $\mathrm{Zn}$ uptake via ivy leaf surface is shown in Fig. 5. Below $\mathrm{pH} 3.0$, i.e. below the isoelectric point of cuticle, $\mathrm{Zn}$ uptake was minimal, increasing up to $\mathrm{pH} 4$ and showing plateau up to $\mathrm{pH}$ 6. The next increase of $\mathrm{Zn}$ uptake is evident at $\mathrm{pH}>6$ what coincides with decrease of zinc concentration in bioavailable $\mathrm{Zn}^{2+}$ form and formation of zinc ionic forms.

\subsection{The effect of temperature}

Our experiments did not confirm the dependence of zinc uptake by ivy leaf surface on temperature within the range from 4 to $37^{\circ} \mathrm{C}$ (results not shown). This problem will require more detailed, mainly kinetics studies. Experiments with isolated cuticular membranes described by SCHÖNHERR and LUBER (2001) showed that different forms of water and lipophilic substances, inorganic ions and charged organic 
molecules penetrate the isolated cuticular membranes independently of temperature. SCHREIBER (2005) concluded that ionic compounds use aqueous polar path of diffusion, whereas lipophilic molecules move along the lipophilic wax and cutin domains. Water, as a small but uncharged molecule, can use both paths.

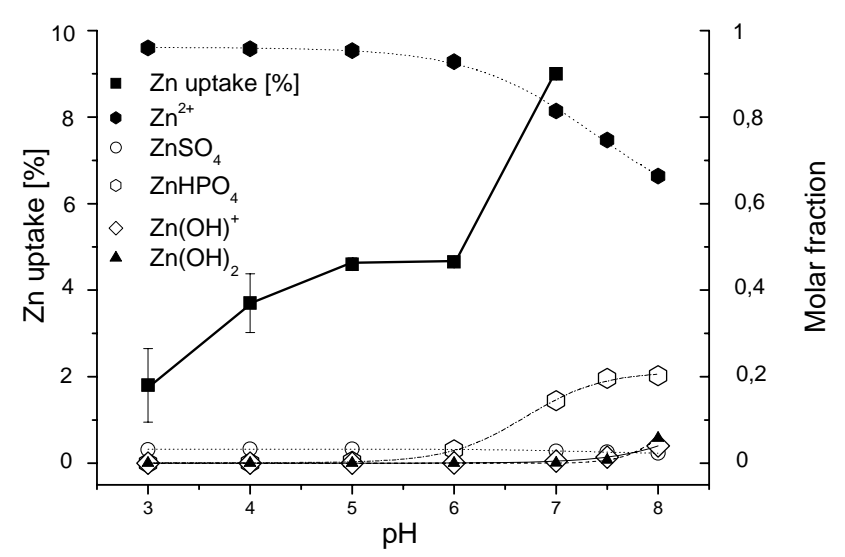

Fig. 5. The pH dependence of Zn uptake via the surface of fully immersed ivy leaves (-m-m-m-) and molar fraction of $\mathrm{Zn}$ species in solutions at given $\mathrm{pH}$ values. Uptake data after $5 \mathrm{~d}$ exposition in $5.0 \mu \mathrm{mol} / \mathrm{dm}^{3}$ $\mathrm{ZnCl}_{2}$ in $25 \% \mathrm{HM}$, spiked with ${ }^{65} \mathrm{ZnCl}_{2}\left(130 \mathrm{kBq} / \mathrm{dm}^{3}\right)$. Initial $\mathrm{pH}$ values adjusted by adding $0.05 \mathrm{M} \mathrm{NaOH}$. Leaf wet weight biomass [g/10 ml]: $0.22 \pm 0.017( \pm \mathrm{SD})$. Leaf area $\left[\mathrm{cm}^{2}\right]: 9.86 \pm 0.88( \pm \mathrm{SD})$. Presented molar fractions of $\mathrm{Zn}$ species at given $\mathrm{pH}$ are calculated by the Visual MINTEQ program.

\section{Conclusions}

Experiments with ivy leaves as a model plant leaves showed that total $\mathrm{Zn}$ uptake from $\mathrm{ZnCl}_{2}$ solution via immersed leaf surface is by one order lower, comparing to $\mathrm{Zn}$ uptake via xylem path of immersed stalks of detached leaves under the same conditions. $\mathrm{Zn}$ uptake increased with increasing initial $\mathrm{Zn}$ concentration up to $\mathrm{C}_{0}=50$ $\mu \mathrm{mol} / \mathrm{dm}^{3} \mathrm{ZnCl}_{2}$ in both cases. Zinc entering the plant tissues via leaf stalks remains bound mainly in stalk and was transported by vascular system into leaf blades only in limited extent. In the last case the specific concentration ratio $[\mathrm{Zn}]_{\text {stalks }} /[\mathrm{Zn}]_{\text {blades }}$ was 120-times higher, compared with the case of zinc entering plant tissues via leaf surfaces. $\mathrm{Zn}$ uptake was minimal below $\mathrm{pH} 3$, increasing at $\mathrm{pH} 3-5$, showing plateau at $\mathrm{pH} 6-7$ and next rapid increase at $\mathrm{pH}$ 7. Our experiments did not confirm the dependence of zinc uptake by ivy leaf surface on temperature. More detailed study is necessary for understanding all factors influencing the efficiency of foliar uptake of mineral nutrients from foliar fertilizers.

\section{References}

BARÁTOVÁ, Z., SEKÁČOVÁ, J., HORNÍK, M., PIPÍŠKA, M., AUGUSTÍN, J.: Bioakumulácia ${ }^{137} \mathrm{Cs}$ a ${ }^{60} \mathrm{Co}$ horčicou bielou Sinapis alba L. a zelerom voňavým Apium graveolens L. Nova Biotechnol., VI-I, 2006, 7-18 (in Slovak). 
BRAMBILlA, M., FORTUNATI, P., CARINI, F.: Foliar and root uptake of ${ }^{134}$ Cs, ${ }^{85} \mathrm{Sr}$ and ${ }^{65} \mathrm{Zn}$ in processing tomato plants (Lycopersicon esculentum Mill.). J. Environ. Radioact., 60, 2002, 351-363.

CANET, D., ROHR, R., CHAMEL, A., GUILLAIN, F.: Atomic force microscopy study of isolated ivy leaf cuticles observed directly and after embeding in Epon ${ }^{\circledR}$. New Phytol., 134, 1996, 571-577.

CHAMEL, A.: Foliar absorption of herbicides: study of the cuticular penetration using isolated cuticles. Physiol. Veg., 24, 1986, 491-508.

FRANKE, R., BRIESEN, I., WOJCIECHOWSKI, T., FAUST, A., YEPHREMOV, A., NAWRATH, C., SCHREIBER, L.: Apoplastic polyesters in Arabidopsis surface tissues - A typical suberin and a particular cutin. Phytochemistry, 66, 2005, 2643-2658.

GILLY, C., ROHR, R., CHAMEL, A.: Ultrastructure and radiolabelling of leaf cuticles from ivy (Hedera helix L.) plants in vitro and during ex vitro acclimatization. Ann. Bot., 80, 1997, 139-145.

HASLETT, B.S., REID, R.J., RENGE, Z.: Zinc mobility in wheat: uptake and distribution of zinc applied to leaves or roots. Ann. Bot., 87, 2001, 379-386.

HOAGLAND, D.R.: Optimum nutrient solutions for plants. Science, 52, 1920, 562564.

HOLDER, C.D.: Leaf water repellency of species in Guatemala and Colorado (USA) and its significance to forest hydrology studies. J. Hydrol., 336, 2007, 147-154.

HORNÍK, M., PIPÍŠKA, M., SEKÁČOVÁ, J., AUGUSTÍN, J.: Determination of long distance transport of $\mathrm{Cs}^{+}, \mathrm{Co}^{2+}$ and $\mathrm{Zn}^{2+}$ ions in vascular plants by autoradiography and gamma-spectrometry. Nova Biotechnol., VII-I, 2007, 33-40.

KRAMER, P.J., KOZLOWSKI, T.T.: Physiology of woody plants. Academic Press, New York, 1979, 378 pp.

LIN, Z.-Q., BARTHAKUR, N.N., SCHUEPP, P.H., KENNEDY, G.G.: Uptake and translocation of ${ }^{54} \mathrm{Mn}$ and ${ }^{65} \mathrm{Zn}$ applied on foliage and bark surfaces of balsam fir [Albies balsamea (L.) Mill.] seedlings. Environ. Exp. Bot., 35, 1995, 475-483.

LIN, H., TAO, S., ZUO, Q., COVENEY, R.M.: Uptake of polycyclic aromatic hydrocarbons by maize plants. Environ. Pollut., 148, 2007, 614-619.

MARSCHNER H.: Uptake and release of mineral elements by leaves and other aerial plant parts. In: Mineral nutrition of higher plants. Elsevier Ltd., 1995, 116-130.

MERCER, G.N.: A simple diffusion model of the effect of droplet size and spread area on foliar uptake of hydrophilic compounds. Pestic. Biochem. Physiol., 88, 2007, 128-133.

PEARSON, J.N., RENGEL, Z.: Uptake and distribution of ${ }^{65} \mathrm{Zn}$ and ${ }^{54} \mathrm{Mn}$ in wheat grown at sufficient and deficient levels of $\mathrm{Zn}$ and $\mathrm{Mn}$ during vegetative growth. J. Exp. Bot., 46, 1995, 833-839.

PEARSON, J.N., RENGEL, Z., JENNER, C.F., GRAHAM, R.D.: Transport of zinc and manganese to developing wheat grains. Physiol. Plantarum, 95, 1995, 449-455.

PEARSON, J.N., RENGEL, Z., JENNER, C.F., GRAHAM, R.D.: Manipulation of xylem transport affects $\mathrm{Zn}$ and $\mathrm{Mn}$ transport into developing wheat grains of cultured ears. Physiol. Plantarum, 98, 1996, 229-234.

SCHLEGEL, T.K., SCHÖNHERR, J., SCHREIBER, L.: Size selectivity of aqueous pores in stomatous cuticle of Vicia faba leaves. Planta, 221, 2005, 648-655. 
SCHÖNHERR, J., HUBER, R.: Plant cuticles are polyelectrolytes with isoelectric points around three. Plant Physiol., 59, 1977, 145-150.

SCHÖNHERR, J., LUBER, M.: Cuticular permeation of potassium salts: effects of humidity, anions and temperature. Plant Soil, 236, 2001, 117-122.

SCHREIBER L.: Polar paths of diffusion across plant cuticles: New evidence for an old hypothesis. Ann. Bot., 95, 2005, 1069-1073.

STEIN, W.D.: The movement of molecules across cell membranes. Academic Press, New York, 1967, 369 pp.

STRACZEK, A., SARRET G., MANCEAU, A., HINSINGER, P. GEOFFROY, N., VIOUGEAS, M.A., ROHR, R., CHAMEL, A.: Structural changes and permeability of ivy (Hedera helix L.) leaf cuticles in retention to leaf development and after selective chemical treatments. New Phytol., 130, 1995, 337-348.

WATANABE, T., YAMAGUCHI, I.: Evaluation of wettability of plant leaf surfaces. J. Pestic. Sci., 16, 1991, 491-498. 